\title{
A profile of Frank Harrison: a pioneering Sheffield dentist from 100 years ago
}

- Identifies the significant achievements of a well respected dentist and pinpoints significant professional dates in his life.

- Examines his family background which is focussed towards dentistry.

- Reveals how the first dental radiographs were taken on patients in the 1890s.

\author{
K. Figures ${ }^{1}$ and C. Smith ${ }^{2}$
}

were taken on patients in the 1890 .

\begin{abstract}
A review of the personal papers relating to Frank Harrison and held by the School of Clinical Dentistry in Sheffield reveal what a dedicated clinician he was and the significance of his achievements from over 100 years ago, both locally and nationally for his chosen profession and also for the people of Sheffield. In addition to being one of the first dentists in the world to experiment with X-rays in dentistry, and the first to write up his findings in a dental journal, he designed and patented dental instruments, wrote books, lectured on fine art (particularly Venetian and Florentine art), and gave lectures to the public in the hope that they would heed his message on the importance of maintaining good oral health. A search of national archives and library resources has added further information about his family and professional accomplishments.
\end{abstract}

\section{FAMILY}

Papers from Frank Harrison's estate were passed to the School of Clinical Dentistry, University of Sheffield, in 1959 by one of his sons (Wilfred Harrison). In addition, the late Professor G. L. Roberts had gleaned information from family members of Frank Harrison and had the foresight to store this in the dental school's archive. The information from these sources has been supplemented by details obtained from census material, from births, marriages and deaths registrations, and from library searches.

Frank Harrison was born in Sheffield on 10 August 1859; his parents were Joseph Harrison and Sophia Harrison (née Sheldon), who had married in the summer of 1842. Joseph had been born on 5 June 1819, the son of John Harrison, a silversmith - or, as White's 1852 Sheffield \& District Directory recorded, a 'manufacturer of nickel silver, patent plated, and Brittania metal wares, and electroplater and gilder, Norfolk Works, 116 Scotland Street. John Harrison died on 6 December

${ }^{1 *}$ Head of Academic Unit of Primary Dental Care ${ }^{2}$ Emeritus Professor of Oral Pathology, University of Sheffield, School of Clinical Dentistry, Claremont Crescent, S10 2TX

${ }^{*}$ Correspondence to: Mr Keith Figures

Email:k.h.figures@sheffield.ac.uk

Refereed Paper

Accepted 9 May 2012

DOI: 10.1038/sj.bdj.2012.931

${ }^{\circledR}$ British Dental Journal 2012; 213: 405-408
1863. Initially it would appear that Joseph was a brass and iron turner and cap and ferrule maker (the same White's Directory and the 1851 census) but later, by the time of the 1857 Post Office Directory for the West Riding and subsequent censuses, he was listed as a dentist or surgeon dentist. In the 1881 census Joseph says he is a Dentist/Licentiate of the Royal College of Surgeons of Ireland (which he had obtained in 1879). Sophia was about the same age as Joseph and her father, John Sheldon, was a cutler.

As well as Frank, other known children of Joseph and Sophia were: Joseph Sheldon Harrison, born about 1844 and described as a dentist by the time he was 17-years-old (and also later); Robert Charles Harrison, born about 1848; Harriet Jane Harrison, born about 1851; and Helen Harrison, born about 1854.

At the age of one, Frank Harrison was living at 30 South Street, Carver Street, Sheffield with his father, mother and four siblings. By the time he had reached the age of 11 his two older brothers were no longer at home and the family had moved to 14 St James Street, Sheffield. It would also appear likely that Frank was at the time a school boarder at Five Oaks, Glossop Road, Sheffield, where the schoolmaster was a clergyman named Thomas Howarth.

In 1881 Joseph and Sophia were then living with their daughter Helen at 289 Glossop Road, Sheffield but Frank by this time was living in Edinburgh, boarding at 10 Brougham Place in the house of John Russell, Master of Works for the City of Edinburgh. Being then 21 years of age, Frank was already a Licentiate of the Royal College of Surgeons of Edinburgh and the presumption is that he was studying for a medical qualification.

By 1891 Frank was back with his mother and father at 289 Glossop Road, Sheffield and both he and his father, then aged 71 years, had the stated occupation of dentist. To complete the story about his parents, Joseph Harrison died on 21 February 1895, aged 75 years, leaving £298.6s.5d in his will; Sophia, his widow, died early in 1909 aged 89 years.

Early in 1892, Frank Harrison married Mary Florence Fieldsend at Southwell, Nottinghamshire. Frank and Mary had five children but we know the names of only four of them: Frank Cecil Harrison (born about 1893); Wilfred Harrison (born about 1894); Eva Harrison (born about 1896); and Mary, or Molly, Harrison (born about 1900). The family were living at 2 Kenwood Bank, Sheffield in 1901 and at 42 Kenwood Road, Sheffield in 1911. Not long after this, on 20 May 1912, Frank Harrison died at 7 Clarkehouse Road, Sheffield (according to the probate records) after an operation; he was 52 years of age and his estate had a value of $£ 8,361$. 7s. $11 \mathrm{~d}$.

The decennial censuses from 1861 to 1911 show that, in common perhaps with 
most families of similar social standing, the households in which Frank Harrison resided were all supported by at least one female servant, and often a cook.

The oldest son of Frank and Mary, Frank Cecil Harrison, qualified both in dentistry and medicine, like his father. During the Great War he was a Captain in the Royal Army Medical Corps and died of wounds received in action on 13 October 1918. At this time his mother, Mary Florence Harrison, was living at 47 Wilkinson Street, Sheffield, where she continued to live until her death at the age of 88 years early in 1956.

\section{PROFESSIONAL CAREER}

Frank had gained an LDSRCS Edinburgh in 1881 and an MRCS England in 1885. He had been educated at the medical schools in Sheffield and in Edinburgh and also at Charing Cross Hospital in London. He joined the British Dental Association in 1884 and at the Cambridge annual meeting in 1885 presented a paper on Antiseptics in dental surgery. ${ }^{1}$ It is evident that Frank by the late 1880s had become one of the leading lights of a group known as the Sheffield Licentiates in Dental Surgery, of which he was at one time President, and whose mission was to lift the profile of dentistry in the eyes of the people of the city. This group also wanted to lift the profile of dentistry among medical colleagues in the city from being seen as an apprentice-based training to one of a professional training finishing with an exit qualification and mirroring the training programmes established in medicine.

His most significant contribution to dentistry is revealed initially, however, in an unidentified press cutting dated 1896 and subsequently in the dental literature reporting the Annual General Meeting of the Midland Branch of the British Dental Association, held in Firth College, Sheffield, when Frank Harrison was elected Branch President. This was to be a most important meeting both for him and subsequently for the dental profession as a whole. At this presidential meeting on 26 June, details of which come from the BDA Library, he presented a paper which was a record of experiments he had undertaken with X-rays to test the value of this new discovery to the science of dentistry. In this paper, entitled The ' $x$ ' rays in the practice of dental surgery, he states 'that $\mathrm{x}$ rays promise to be of great use in dentistry' but goes on to say that 'he would not advise anyone unless he has some good help and plenty of time to commence an investigation'. He showed by a number of lantern slides of the 'Roentgen shadow graphs' that 'the employment of the rays will be most useful'. It is interesting to reflect now on the technique he used to take intraoral radiographs and quoted here: 'The film is cut to the required size and enclosed in black paper and then covered with rubber dam; if in the upper jaw a small square simply laid over the film is sufficient to protect it, but if in the lower jaw, it must be completely enclosed in rubber. The whole is then held in position with a frame of stent which has been previously adjusted to the required area and held in place by closing the teeth upon it much after the form of an interdental splint.' He comments that "with an exposure time of six minutes some "contrapshun" needs to be arranged to keep the film still and protected from moisture.' With care all of the teeth of the patient could be shown on the photographic film as they existed in situ. He pointed out how useful X-rays would be in the provision of artificial crowns, the treatment of roots and in cases of difficult eruption of teeth. However, he also went on to comment on the fact that one of his assistants, who was an enthusiast for the new X-rays, had discovered that the regular application of X-rays to his face had the result of destroying the hair of his beard and moustache. ${ }^{2}$ This tissue response seen in the early days of dental radiography is expanded on in the original text as follows: 'One of my assistants who has been equally devoted and enthusiastic in these experiments, acting alternatively the part of patient and operator, has developed trouble which I will report to you. On May $6^{\text {th }}$ the patient was first subjected to effects of the xrays, but with an ordinary Crookes tube. The right side of his face was chosen as being the most accessible. Between this date and the $20^{\text {th }}$ some dozen exposures were made varying in duration from 10 to 40 minutes. The current generated by a four cell accumulator charged with eight volts and 5 amperes. On $22^{\text {nd }}$ May a French focus tube was used, Whitsuntide intervened, causing an interval of one week, after which time we resumed the experiments with a Newton's tube, with a new secondary battery and eight volts and 8 amps. Exposures were made on May 28,29, and 30, the last one being on June $1^{\text {st }}$. On June $4^{\text {th }}$ the patient complained of an itching and burning sensation and shaving had to be stopped on account of pain. On the $6^{\text {th }}$ June the area had the appearance of a local erysipelas with a sharp line of demarcation and the beard and the right side of the moustache had begun to pustulate. On the $9^{\text {th }}$ of June hair began to be lost and this continued up until the time of writing ( $24^{\text {th }}$ June)'.

He reflects on this radiation damage by concluding "on the sixth day after the exposure with the Newton tube the irritation commenced and was followed by the falling of the hair on the eighth day'. He goes on to summarise that this work is altogether too complicated and too expensive to be included in everyday dental practice at this point in time but has definite implications for dentistry in the future. ${ }^{2}$

The press cutting mentioned earlier concludes by stating that Mr Geddes of Harrogate, in seconding the vote of thanks, said that it was of great satisfaction to the Midland Branch of the BDA that their Sheffield President should have been the pioneer in the application of $\mathrm{X}$-rays to dental work.

On the same day in 1896 as his election to Branch President the new dental department of the Sheffield Royal Hospital was opened. At the opening of this new venture Professor Arthur Hall, the Dean of Medicine, noted in his address that it was due to Mr Frank Harrison, who in 1892 wanted to do something to advance dentistry in Sheffield and had approached the Medical School with that end in mind. In 1895, when the new outpatients department was opened, accommodation was then found to house the dental department, which was also intended to be used for the training of a few dental students once Royal College approval of the course and the facilities had been obtained.

Frank Harrison (Fig. 1) held many positions of influence in the city, including President of the Sheffield Microscopical Society, Demonstrator of Physiology in the Sheffield Medical School, as well as Honorary Dental Surgeon at Totley Orphanage. He was also Honorary Dental 


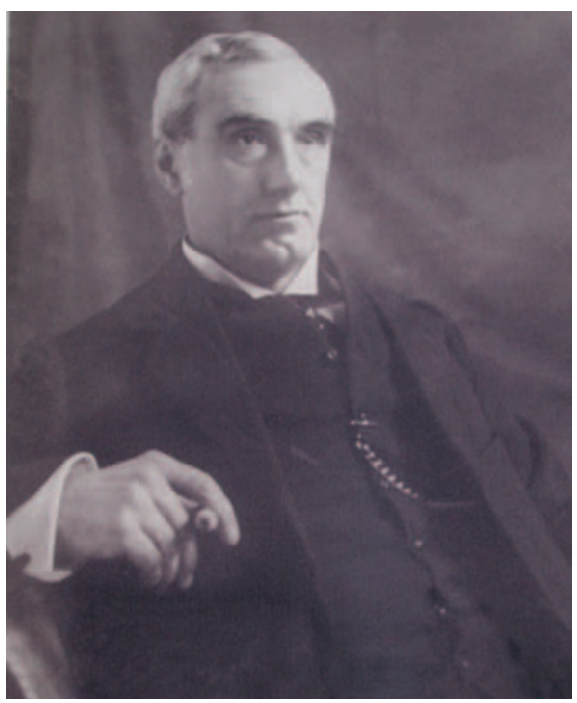

Fig. 1 A photograph of Frank Harrison taken in his early forties

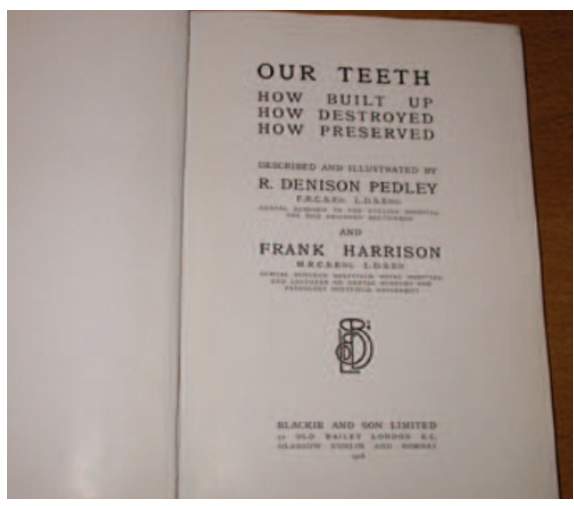

Fig. 2 A copy of his book published in 1908

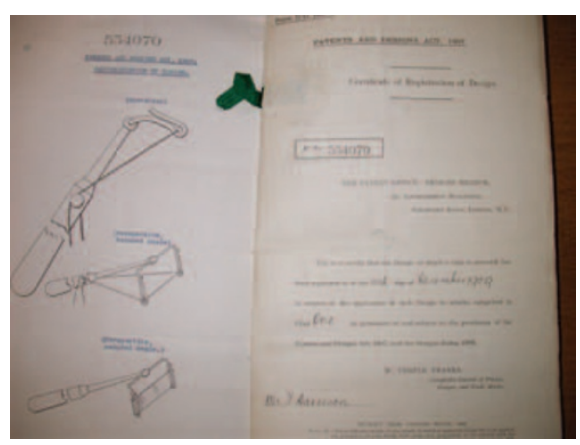

Fig. 3 The actual patent granted in 1909 for his design of a floss holder which could also be used as a dental matrix retainer

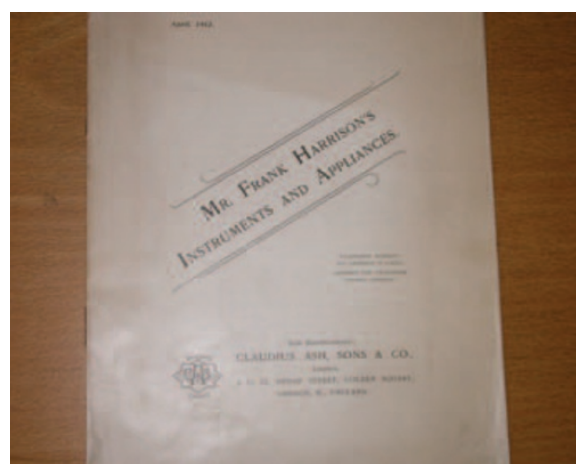

Fig. 4 His instrument catalogue published in April 1912
Surgeon to the Sheffield Royal Hospital and Lecturer in Dental Surgery and Pathology at the University of Sheffield.

In 1906, one year after the University of Sheffield had received its Royal Warrant from King Edward VII, he gave an open lecture in Firth Hall of the new university for the benefit of those who wanted to attend. The title of this lecture was 'Our teeth and why we should take care of them. By way of introduction to this lecture he opened by saying that 'the ravages made by caries of the teeth of our children and adolescents is not a matter to make light of. It is a serious menace to health. Those interested in Public Health must recognize the importance of seriously considering a disease which is today lowering the vitality of thousands of our citizens'. He then moves on to describe in detail normal tooth structure and also the importance of bacteria which destroy this structure and which he divides into 'acid producing and which dissolve the lime out of the tooth at a weak spot and petronizing those which feed on the gelatinous material left when the lime has dissolved'. Dietary issues are addressed where he talks about dental disease in this context and reflects that 'all dental observers in Sheffield are convinced of one thing, that children who have been breast fed have by far better teeth than those who have been brought up by hand'. He went on to say that 'nature's chemistry is far better than that of the chemical laboratory, although the latter may be very useful in an emergency. The archive has his annotated notes for this lecture still in their original condition.

On the occasion of his Presidential address $^{3}$ to the British Medical Association's Section of Dental Surgery held in Sheffield in July 1908, Frank Harrison emphasised 'the fact that dental disease is the most widespread and commonest of all diseases' and demonstrated his insight and ambition by then saying 'What an opportunity presents itself for one of our modern universities, fully equipped with all the latest scientific instruments and expert professors, to solve this problem of the cause of dental caries.

In collaboration with Dr Denison Pedley he wrote an illustrated book entitled Our teeth (Fig. 2) aimed at the general public. In the preface to this book the two authors reveal their intention to write and illustrate such a book 'for all who take an interest in their own health and in the welfare of the community'. They go on to outline their view that 'in order to cope adequately and effectively with preventable diseases it would be necessary to inaugurate a public medical service in connection with the homes and the schools throughout the country. In this should be included an efficient dental service. Systematic examination of the school children must be followed by systematic treatment. An extension of the responsibility in this matter, of those who control the education of the young, is also necessary: ${ }^{4}$ This is a recurring theme in Harrison's thinking and crops up quite often. In addition it is interesting to record one of the reviews of this book which was reported in Ash's Monthly, January 1911 (the catalogue of the dental instrument manufacturer): ${ }^{5}$ The style [of the book] throughout is lucid and interesting, the illustrations quite remarkably good and well produced. The authors are to be congratulated upon having produced a thoroughly clear and useful manual. - Nature'

As a result of this belief and stance he was subsequently consulted by Sheffield Education Committee with regard to the formation of the first school dental clinic in the city.

\section{AN INSIGHT INTO THE MAN}

His ingenuity revealed itself in the form of a number of dental inventions, some of which he patented. One of his patents granted on 14 December 1909 is shown in Fig. 3 and describes a dental floss holder which could also double as a matrix retainer when placing restorations. In April 1912 the dental manufacturer Claudius Ash and Son published another catalogue of instruments he had designed which included designs for a cotton roll holder, a hydraulic plugger for placing and finishing amalgam restorations, together with the matrix holder the patent of which is shown in Figure 3. Also advertised is an illustrated booklet containing his own drawings on how caries affected the teeth (Fig. 4). ${ }^{6}$

He was a prominent freemason, having been initiated into the Brunswick Lodge by his father. Later he joined the St Leonard's Lodge and held the position of Worshipful Master up until his death. He 
was a member of the White Rose Chapter, Registrar of the Furnival Preceptory of Knight Templars, and was Past Provincial Herald in the same order. ${ }^{7}$

His life came to a premature and quite abrupt end at the age of 52 on 20 May 1912 after a short illness and resulting operation. There were a number of obituaries written in the professional journals at the time but one of the best and most detailed was written by his friend and coauthor R. Denison Pedley. He records that 'Frank Harrison was a student of art and a long admirer of Ruskin and of course could study his works in the Ruskin Museum in Sheffield. Fond of sketching and an expert in photographic art, he spent many of his annual holidays in exploring the art treasures of European cities. Italy was his favourite country and he had knowledge of painting and sculpture beyond most of his fellows. He gave a number of lectures on Venetian and Florentine art.' When entertaining at home he was apparently a splendid host and delighted in making his friends happy. His house was adorned with works of art and he enjoyed bringing together people with diverse tastes but a kindred sprit to enjoy his enthusiasm for art, music and science. With his devoted wife and children he seemed at his best. This obituary ends with, 'to leave this world a little better than one finds it is a

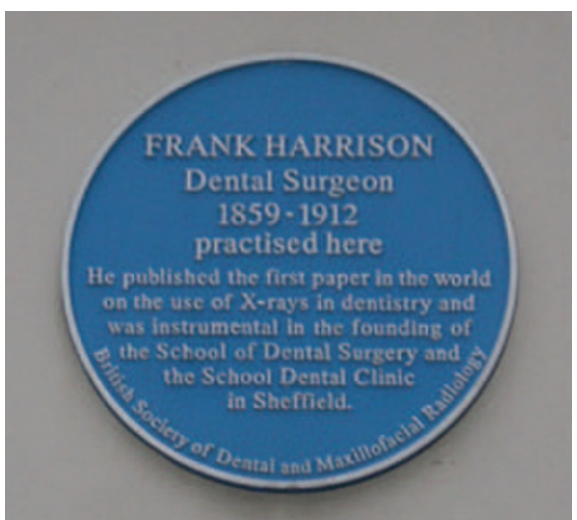

Fig. 5 The blue plaque placed by the British Society of Dental and Maxillofacial Radiology on his former practice premises at $\mathbf{2 8 9}$ Glossop Road, Sheffield

lofty ambition. In that he was successful and his example is one we may well strive to follow."

The blue plaque (Fig. 5) which is placed on his former dental practice building in Glossop Road, thought to be built around 1825 , is now a property owned by the University of Sheffield. This plaque was placed in 2005 by Keith Horner, Professor of Maxillofacial Imaging at the University of Manchester and then President of the British Society of Dental and Maxillofacial Radiology. It is believed that this plaque is one of only three in the UK devoted to a dentist. The others are to James Robinson at 14 Gower Street in London, who pioneered anaesthesia and dentistry, and to
George Cunningham 'the father of preventive dentistry' in Cambridge. ${ }^{9}$

A summary of his achievements:

1. He wrote one of the first scientific papers on the use of radiography in dentistry

2. He established the need for a dental school in Sheffield and was there at its opening in 1896

3. He designed many dental instruments, some of which he patented

4. He gave public lectures in various places on dental disease and the importance of controlling it

5. He was instrumental in establishing the first school dental clinic in Sheffield to improve the dental health of children in the city.

We thank Helen Nield of the BDA Library for her help in researching material for this article.

1. Obituary. Frank Harrison MRCS, LDS. Br Dent J 1912; 33: 532-533

2. Harrison $F$. The ' $x$ ' rays in the practice of dental surgery. J Br Dent Assoc 1896; 17: 624-628.

3. Harrison F. President's Address, Section of Dental Surgery, Seventy-Sixth Annual Meeting of the British Medical Association. Br Med J 1908; 2: 459

4. Denison Pedley R, Harrison F. Our teeth: how built up, how destroyed, how preserved. London: Blackie and Son, 1908.

5. Ash's Monthly. Golden Square, London: Claudius Ash and Sons and Co Ltd, January 1911.

6. Harrison F. Mr Frank Harrison's instruments and appliances. London: Claudius Ash, Sons and Co Ltd, 1912.

7. Obituary. Sheffield Daily Telegraph, 21 May 1912.

8. Denison Pedley R. Obituary. Frank Harrison. Br J Dent Sci 1912: 55: 477-480.

9. Hirschmann P. Frank Harrison (1859-1912). Dent Hist 2006; 43: 62-66. 